Article

\title{
New Alkaloid and Aromatic Glucoside from the Flowers of Cymbidium Lunagrad Eternal Green
}

\author{
Li-Yan Song, Fang Huang, Yan Wang, Zu-Jian Wu and Ming-An Ouyang * \\ State Key Laboratory of Ecological Pest Control for Fujian and Taiwan Crops, Institute of Plant Virology, \\ Fujian Agriculture and Forestry University, Fuzhou 350002, Fujian, China; slywinter@163.com (L.-Y.S.); \\ fafuhf12@163.com (F.H.); fafuwy12@163.com (Y.W.); wuzujian@126.com (Z.-J.W.) \\ * Correspondence: minganouyang@163.com; Tel.: +86-150-059-957-02
}

Received: 30 November 2017; Accepted: 30 December 2017; Published: 3 January 2018

\begin{abstract}
In this paper, we investigated the chemical components of the flowers of Cymbidium Lunagrad Eternal Green for the first time. In the whole post-fertilization, a new alkaloid, named Lunagrad A (1), and a new aromatic glucoside, named Lunagrad B (2), were isolated from the $\mathrm{MeOH}$ extract of the flowers of Cymbidium Lunagrad Eternal Green, along with other six known aromatic compounds (3-8) and three flavone glucosides (9-11). These structures were determined on the basis of NMR experiments, as well as chemical evidence.
\end{abstract}

Keywords: orchid; Cymbidium Lunagrad Eternal Green; alkaloid; aromatic glucoside; flavone glycoside; natural product

\section{Introduction}

Since ancient times, numerous orchid species have been used in different countries for apparent ornamental and medicinal value. Cymbidium hybridum is one of the most popular pot orchids worldwide, which contains a huge number of cultivars with large flowers. Commercial Cymbidium hybridum includes some wild species in genus of Cymbidium and lots of hybrid cultivars through inter-specific hybridization between 20 Cymbidium species of terrestrial and epiphytic orchids. The natural parent species of Cymbidium hybridum could trace back to its primal putative parents Cymbidium eburneum (maternal parent) and Cymbidium lowianum (paternal parent) in 1889 [1-3]. However, very little is known about the chemical or bioactive substances of these cultivars. To the best of our knowledge, only one Cymbidium hybridum, Cymbidium Great Flower Marylaurencin, has been chemically investigated, leading to the identification of phenanthrene derivatives and aromatic constituents, which showed certain biological activities [4-7].

In this paper, we investigated the chemical components of the flowers of Cymbidium Lunagrad Eternal Green for the first time. In the whole post-fertilization, a new alkaloid, named Lunagrad A (1), and a new aromatic glucoside, named Lunagrad B (2), were isolated (Figure 1). We describe here the isolation, purification, and structural elucidation of $\mathbf{1}$ and $\mathbf{2}$, primarily determined by extensive NMR experiments.

In addition, six known aromatic compounds (2R)-2-benzyl-2-hydroxysuccinic acid (3) [8], marylaurecinosides B (4) [5], grammatophylloside B (5) [9], gastrodin (6) [10], arbutin (7) [11], and sakakin (8) [12], together with three flavone glucosides, ermanin (9) [13], quercetin 3-O- $\alpha-\left(2^{\prime \prime}-O-\alpha\right.$-L-rhamnopyranosyl- $\beta$-D-glucopyranoside (10) [14], and orientin (11) [15] were found. The known structures (Figure 2) were identified by comparison of their spectroscopic data with those reported in the literature. It is noteworthy that compounds 3-8 were also obtained from the flowers of Cymbidium Great Flower Marylaurencin [7]. 

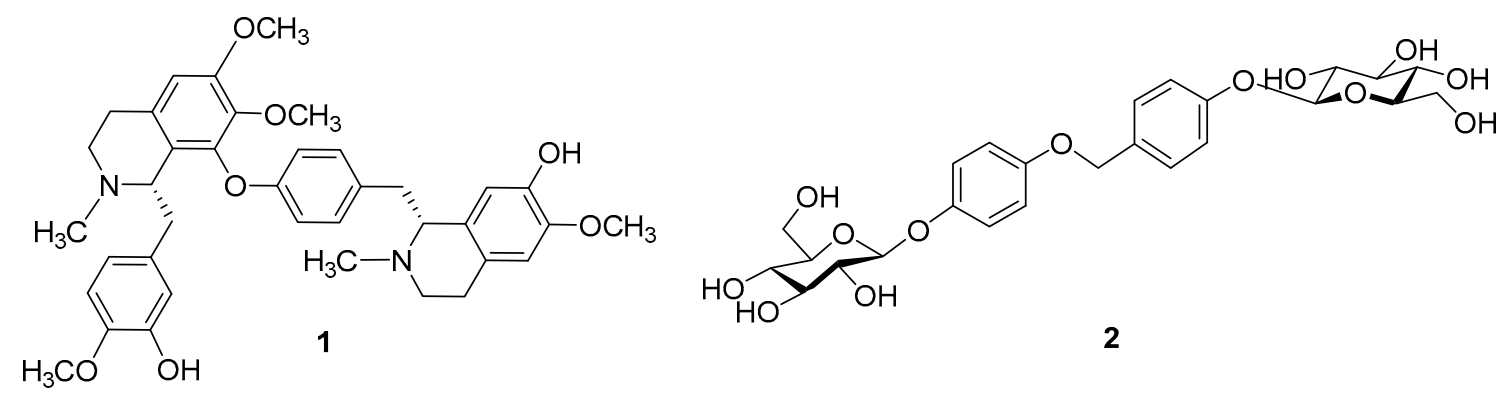

Figure 1. Two new compounds $\mathbf{1}$ and $\mathbf{2}$ isolated from the flowers of Cymbidium Lunagrad Eternal Green.<smiles>[R20]OC(=O)CC(O)(Cc1ccccc1)C(=O)O[R]</smiles>

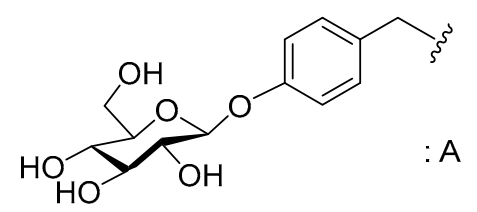<smiles>[R]c1cc(O[GeH3])cc([R2])c1[R]</smiles>

\section{$6 \quad \mathrm{R}_{1}=\mathrm{H}, \quad \mathrm{R}_{2}=\mathrm{CH}_{2} \mathrm{OH}, \mathrm{R}_{3}=\mathrm{H}$;}

$$
\begin{array}{lll}
7 \mathrm{R}_{1}=\mathrm{H}, \mathrm{R}_{2}=\mathrm{OH}, & \mathrm{R}_{3}=\mathrm{H} ; \\
8 \mathrm{R}_{1}=\mathrm{OH}, \mathrm{R}_{2}=\mathrm{H}, & \mathrm{R}_{3}=\mathrm{CH}_{3}
\end{array}
$$<smiles>[R]c1ccc(-c2oc3c([R])c(O)cc(O)c3c(=O)c2[R])cc1[R]</smiles>

$9 \mathrm{R}_{1}=\mathrm{H}, \quad \mathrm{R}_{2}=\mathrm{H}, \quad \mathrm{R}_{3}=\mathrm{OCH}_{3}, \mathrm{R}_{4}=\mathrm{OCH}_{3}$;

$10 \mathrm{R}_{1}=\mathrm{H}, \quad \mathrm{R}_{2}=\mathrm{OH}, \mathrm{R}_{3}=\mathrm{OH}, \quad \mathrm{R}_{4}=\alpha$-L-Rha- $(1 \rightarrow 2) \beta-\mathrm{O}-\mathrm{Glu}$;

$11 \mathrm{R}_{1}=\mathrm{Glu}, \mathrm{R}_{2}=\mathrm{OH}, \mathrm{R}_{3}=\mathrm{OH}, \quad \mathrm{R}_{4}=\mathrm{H}$.

Figure 2. Nine known compounds 3-11 isolated from the flowers of Cymbidium Lunagrad Eternal Green.

\section{Results and Discussion}

Lunagrad A (1) was identified as a bisbenzyltetrahydroisoquinoline alkaloid (BBIQA) derivative. The BBIQAs represent a large and important class of natural products, which have received great attention due to their wide range of pharmacological activities [16-21]. Compound 1 was obtained as a slightly yellow amorphous powder and showed an $[\mathrm{M}+\mathrm{H}]^{+}$ion peak at $\mathrm{m} / \mathrm{z}=641.3230$ (calcd. 641.3227) in the HR-MS (ESI), which corresponded to the molecular formula $\mathrm{C}_{38} \mathrm{H}_{44} \mathrm{~N}_{2} \mathrm{O}_{7}$. ${ }^{13} \mathrm{C}-\mathrm{NMR}$, edited HSQC, and HMBC spectra (Supplementary Information Figures S3-S8) of compound 1 displayed 38 carbon resonances, assignable to ten aromatic tertiary carbons $\left(\delta_{C} 107.3,113.2,113.7,116.7,121.4,122.8,122.9,124.4,131.8,133.9\right), 14$ aromatic quaternary carbons $\left(\delta_{C} 124.0,129.0,129.1,129.3,135.8,136.7,139.3,153.0,149.4,148.7,151.0,150.3,145.2,155.1\right)$, two aliphatic methines $\left(\delta_{C} 63.0,64.5\right)$, six aliphatic methylenes $\left(\delta_{C} 23.7,26.0,37.5,42.6,45.3,45.7\right)$, two $\mathrm{NCH}_{3}\left(\delta_{\mathrm{C}} 42.5,43.1\right)$, and four $\mathrm{OCH}_{3}$ groups $\left(\delta_{\mathrm{C}} 56.1,56.4,56.8,60.7\right)$ that are connected to aromatic rings. The NMR data featured a 1,4,5-trisubstituted benzene moiety [ $\delta_{\mathrm{H}} 6.56(\mathrm{~s}) \mathrm{H}-13 ; \delta 6.92$, $6.86(2 \mathrm{H}$, both $\mathrm{d}, J=8.2 \mathrm{~Hz}) \mathrm{H}-16, \mathrm{H}-17]$, and a 1,4-disubstituted benzene moiety $\left[\delta_{\mathrm{H}} 7.43,7.05\right.$ $(2 \mathrm{H}$, both d, $J=8.2 \mathrm{~Hz}) \mathrm{H}-13^{\prime}, \mathrm{H}-14^{\prime} ; \delta_{\mathrm{H}} 6.76,6.38(2 \mathrm{H}$, both $\left.\mathrm{d}, J=8.2 \mathrm{~Hz}) \mathrm{H}-16^{\prime}, \mathrm{H}^{\prime}-17^{\prime}\right]$, together with three aromatic proton singlets $\left(\delta_{\mathrm{H}} 6.42, \mathrm{H}-6 ; \delta 6.66, \mathrm{H}-6^{\prime} ; \delta 6.01, \mathrm{H}-9^{\prime}\right)$ [21]. The NMR spectrum of compound 1 exhibited two $\mathrm{N}$-methyl signals $\left[\delta_{\mathrm{H}} 2.27,2.62\right.$ (s) $\left.\mathrm{H}-2, \mathrm{H}-2^{\prime}\right]$ and four $\mathrm{O}$-methyl signals $\left[\delta_{\mathrm{H}} 3.15,3.37,3.73,3.89\right.$ (s) $\mathrm{CH}_{3} \mathrm{O}-8, \mathrm{CH}_{3} \mathrm{O}-7^{\prime}, \mathrm{CH}_{3} \mathrm{O}-7, \mathrm{CH}_{3} \mathrm{O}-15$ ] (Supplementary Information Figure S2). Furthermore, compound $\mathbf{1}$ is an isomer of well-known dauricine's analogues [18-20]. The structure of dauricine was established as a head-to-tail BBIQA by spectroscopic data [21]. 
However, the HMBC spectrum of $\mathbf{1}$ showed the expected $\mathrm{C}-\mathrm{H}$ correlations via two and three bonds within the two tetrahydroisoquinoline units, but gave no additional information about the connectivity of the two moieties (head-to-tail, tail-to-tail, or head to head; no correlations via four bonds were observed; SI Figure S9). In addition, H-11/11' correlated with the aromatic carbons C-10/10', C13/13' and $\mathrm{C} 17 / 17^{\prime}$ (Supplementary Information Figure S9). Analysis of the ROESY spectrum suggested the methoxy position to aromatic rings [correlations between $\mathrm{H}-6, \mathrm{CH}_{3} \mathrm{O}-7$, and $\mathrm{H}-6^{\prime}, \mathrm{CH}_{3} \mathrm{O}-7^{\prime}$, and $\mathrm{H}-16$, $\mathrm{CH}_{3} \mathrm{O}-15$, respectively; Supplementary Information Figure S10]. Collectively, these data indicate the structure of the new compound Lunagrad A (1) as shown in Figure 1.

Lunagrad B (2) was obtained as a white amorphous powder. The molecular formula, $\mathrm{C}_{25} \mathrm{H}_{32} \mathrm{O}_{13}$, which requires ten degrees of unsaturation, was determined on the basis of the $[\mathrm{M}+\mathrm{H}]^{+}$ion peak at $m / z=541.1917$ (calcd. 541.1921) in the HR-MS (ESI) . The acid hydrolysis of 2 gave D-glucose, which was identified after derivatization by GC-MS. The $\beta$ stereochemistry was determined by the coupling constants of the anomeric hydrogen $(7.2 \mathrm{~Hz})$. The ${ }^{1} \mathrm{H}$ and ${ }^{13} \mathrm{C}-\mathrm{NMR}\left(\mathrm{CD}_{3} \mathrm{OD}\right)$ spectra of 2 (Supplementary Information Figures S11 and S13), which were assigned by two-dimensional (2D) gradient NMR experiments (HSQC, HMBC, COSY) (Supplementary Information Figures S14-S17), showed benzyloxy protons [ $\delta 4.54(2 \mathrm{H}, \mathrm{s}) \mathrm{H}-1]$, and two $\mathrm{A}_{2} \mathrm{~B}_{2}$ systems specific to a para-substituted aromatic pattern $\left[\delta 7.02,7.27\right.$ (2H each, both $\mathrm{d}, J=8.4 \mathrm{~Hz}$ ) H-2 ${ }^{\prime} / 6^{\prime}, \mathrm{H}-3^{\prime} / 5^{\prime} ; \delta 6.69,6.96(2 \mathrm{H}$ each, both $\mathrm{d}$, $J=8.8 \mathrm{~Hz}$ ) H-2 ${ }^{\prime \prime} / 6^{\prime \prime}, \mathrm{H}-3^{\prime \prime} / 5^{\prime \prime}$ ] (Supplementary Information Figure S14). In the HMBC experiment of 2, $\mathrm{H}-1$ correlated with the aromatic $\mathrm{C}-1^{\prime}$ and $\mathrm{C}-2^{\prime} / 6^{\prime}\left(\delta_{\mathrm{C}} 136.6,129.5\right)$. The chemically equivalent $\mathrm{H}-2^{\prime} / 6^{\prime}$ aromatic protons correlated with $C-1\left(\delta_{C} 64.9\right), C-1^{\prime}\left(\delta_{C} 136.6\right)$ and the oxygenated $C-4^{\prime}\left(\delta_{C} 158.5\right)$. In addition, the chemically equivalent $\mathrm{H}-2^{\prime \prime} / 6^{\prime \prime}$ aromatic protons correlated with the oxygenated $C-1^{\prime \prime} / 4^{\prime \prime}\left(\delta_{C} 152.5,153.9\right)$ (Supplementary Information Figure S16). The HSQC spectrum clearly showed two glucopyranosyl pattern and two correlation between the anomeric proton $(\delta 4.73)[(2 \mathrm{H}, \mathrm{d}$, $J=7.2 \mathrm{~Hz}), \mathrm{H}-4^{\prime}-\mathrm{O}-\mathrm{Glu}-1$ and $\left.\mathrm{H}-4^{\prime \prime}-\mathrm{O}-\mathrm{Glu}-1\right]$ and the anomeric carbons $\left(\delta_{C} 102.4,103.7\right)$ (Supplementary Information Figure S15). On the basis of these findings, the structure of the new compound Lunagrad B (2) was formulated as shown in Figure 3.
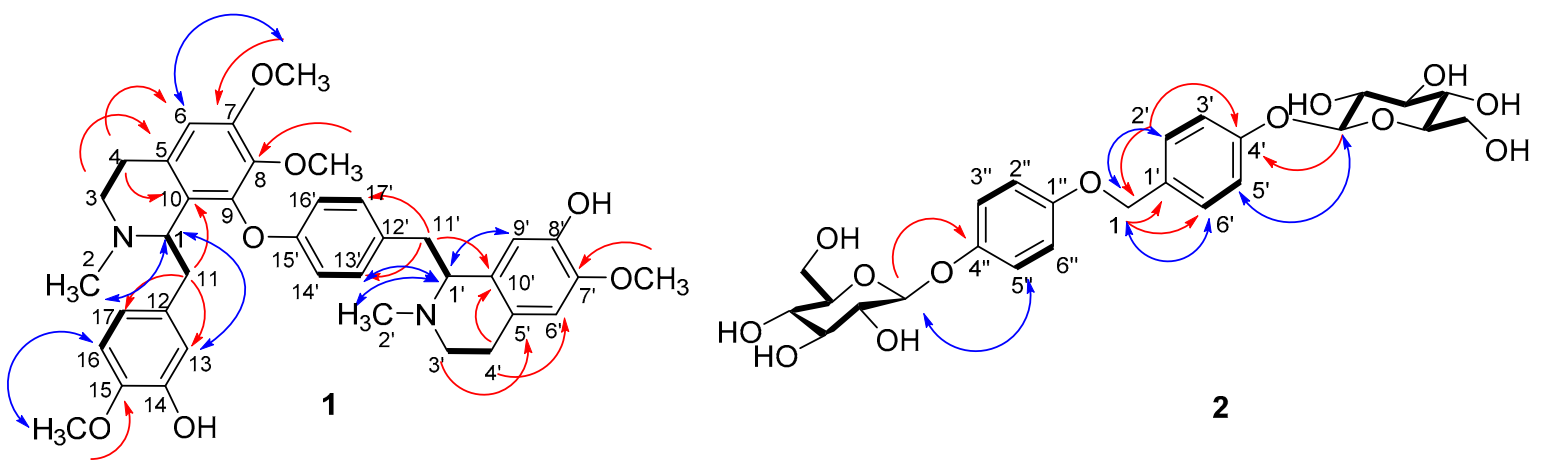

Figure 3. Key COSY (thick lines), HMBC $(\mathrm{H} \rightarrow \mathrm{C})$ and ROESY $(\leftrightarrow)$ correlations of $\mathbf{1}$ and $\mathbf{2}$.

\section{Experimental Section}

\subsection{General}

GC-MS and EIMS, Trace GS Ultra equipped with a capillary TR-5MS SQC column $(0.25 \mu \mathrm{m}$, $15 \mathrm{~m} \times 0.25 \mathrm{~mm}$ i.d.) and DSQII Thermo Scientific mass spectrometer. High resolution mass spectra were measured at Keecloud Mass Spectrometry Service Company on a Thermo Scientific LTQ Orbitrap XL system. Optical rotations were measured on a JASCO-1020 polarimeter (JASCO, Tokyo, Japan). Infrared spectra were collected on a Bruker model TENSOR27 spectrophotometer (Bruker Optics, Ettlingen, Germany). All of the NMR spectra were obtained using a Bruker AVANCE III 500 spectrometer (Bruker BioSpin, Rheinstetten, Germany). Sephadex LH-20 (25-100 m, Pharmacia Fine Chemical Co., Ltd., Uppsala, Sweden), D101/D201 macroporous adsorption resin (Dalian Elite Analytical Instrument 
Co. Ltd., Dalian, China), MCI GEL CHP20P (Mitsubishi Chemical Co., Tokyo, Japan), C18 reversed-phase silica gel (230-400 mesh, Sigma-Aldrich, St. Louis, MO, USA), Silica gel (200-300 mesh), and Silica gel H (Qingdao Oceanic Chemical Co., Ltd., Qingdao, China) were used for column chromatography. Thin-layer chromatography (TLC) was performed on glass-backed plates coated with $0.25 \mathrm{~mm}$ layers of Silica gel H (Qingdao Oceanic Chemical Co., Qingdao, China). Fractions were monitored by TLC and spots were visualized by heating silica gel plates sprayed with $5 \% \mathrm{H}_{2} \mathrm{SO}_{4}$ in $\mathrm{EtOH} / \mathrm{H}_{2} \mathrm{O}(1 / 1)$. All of the solvents and chemicals that were used were of analytical reagent grade (Sinopharm Chemical Reagent Co., Ltd., Beijing, China), and water was doubly distilled before use.

\subsection{Plant Material}

Cymbidium Lunagrad Eternal Green was purchased from Fujian Flower Market, Fujian Province, People's Republic of China, in September 2012 and identified by Prof. Shi-Pin Chen, Forestry College, Fujian Agriculture and Forestry University. A voucher specimen (No. 070612) was deposited in the Forestry College, Fujian Agriculture and Forestry University.

\subsection{Extraction and Isolation}

The flower organs of the plant (air-dried, $36 \mathrm{~g}$ ) were extracted with $\mathrm{MeOH}(2 \mathrm{~L}, 3 \mathrm{~d})$ at room temperature for three times and the combined organic phase was concentrated in vacuum via a rotavap. The residue was subjected to D101 macroporous adsorption resin and then filtered to give $9 \mathrm{~g}$ of crude extract. The extract was subjected to D201 macroporous adsorption resin with a $\mathrm{H}_{2} \mathrm{O} / \mathrm{MeOH}$ elution gradient (from $100 \% \mathrm{H}_{2} \mathrm{O}$ to $100 \% \mathrm{MeOH}$ ) to yield 10 fractions (Fractions 1-10).

Fraction $2(608 \mathrm{mg})$ was subjected to silica gel column chromatography $\left(\mathrm{CHCl}_{3} / \mathrm{MeOH}, 20: 1\right)$ to give $10\left(18.7 \mathrm{mg}, R_{\mathrm{f}}=0.20, \mathrm{CHCl}_{3} / \mathrm{MeOH}=10: 1\right)$.

Fraction $3(1.30 \mathrm{~g})$ was subjected to Sephadex LH-20 column chromatography eluted with $\mathrm{MeOH}$ to afford four fractions 3-1-3-4. Fraction 3-1 was further purified by RPC column chromatography $\left(\mathrm{MeOH} / \mathrm{H}_{2} \mathrm{O}, 1: 1\right)$ to afford $1(60.7 \mathrm{mg})$. Fraction 3-3 was purified by $\mathrm{MCI}$ column chromatography $\left(\mathrm{MeOH} / \mathrm{H}_{2} \mathrm{O}, 3: 5\right.$ to 1:0) to afford 6 (20.3 mg). Fraction 3-4 was obtained as white powder (2, $\left.26.4 \mathrm{mg}\right)$. A solution of 2 in $2 \mathrm{M}$ hdrochloric acid $(0.5 \mathrm{~mL})$ was heated to reflux for $3 \mathrm{~h}$. The solution was extracted with $t$-butyl alcohol. The dried residue of the aqueous layer was derivatized by pyridine and 1-(trimethylsilyl)-imidazole at $60^{\circ} \mathrm{C}$ for $1 \mathrm{~h}$. The mixture was analyzed by GC-MS (Trace GS Ultra) with a capillary TR-5MS SQC column $(0.25 \mu \mathrm{m}, 15 \mathrm{~cm} \times 0.25 \mathrm{~mm})$ under the following conditions: $1 \mathrm{~min}$ at $40^{\circ} \mathrm{C}$, increase of temperature with a thermal ramp of $10^{\circ} \mathrm{C} / \mathrm{min}$ until $250^{\circ} \mathrm{C}$ (helium flow rate $1 \mathrm{~mL} / \mathrm{min}$, injector temperature $250^{\circ} \mathrm{C}$, transfer temperature $285^{\circ} \mathrm{C}$ ). Impact electronic detection was performed with a DSQII Thermo Scientific mass spectrometer. Identification of D-glucose was carried out by a comparison of its retention time and spectroscopic data with those of an authentic sample of D-glucose (Purchased from Aldrich), $t_{\mathrm{R}} 14.8 \mathrm{~min}$.

Fraction $4(1.50 \mathrm{~g})$ was subjected to D201 macroporous adsorption resin with a $\mathrm{H}_{2} \mathrm{O} / \mathrm{MeOH}$ elution gradient $\left(\mathrm{H}_{2} \mathrm{O} / \mathrm{MeOH}, 9: 1\right.$ to 1:4) to yield 6 fractions 4-1-4-6. Fraction 4-3 was obtained as white powder $(5,39.2 \mathrm{mg})$. Fraction $4-4$ was subjected to silica gel column chromatography (petroleum ether/acetone, 10:1 to 1:1) to yield $4\left(23.2 \mathrm{mg}, R_{\mathrm{f}}=0.26, \mathrm{CHCl}_{3} / \mathrm{MeOH}=10: 1\right)$ and $9(30.1 \mathrm{mg})$. Fraction 4-5 was purified by MCI column chromatography eluting with $\mathrm{MeOH}$ to afford $8(12.6 \mathrm{mg})$.

Fraction $7(1.20 \mathrm{~g})$ was subjected to silica gel column chromatography $\left(\mathrm{CHCl}_{3} / \mathrm{MeOH}, 30: 1\right.$ to 3:1) to yield 6 fractions 7-1-7-6. Fraction 7-2 was obtained as a white powder $(3,25.0 \mathrm{mg})$. Fraction 7-3 was purified by $\mathrm{MCI}$ column chromatography $\left(\mathrm{H}_{2} \mathrm{O} / \mathrm{MeOH}, 2: 3\right)$, to afford 7 (39.4 mg).

Fraction $8(910 \mathrm{mg})$ was subjected to silica gel column chromatography (petroleum ether/acetone, 20:1 to 2:1) to yield 5 fractions 8-1-8-5. Fraction 8-5 was obtained as yellow powder (11, $19.6 \mathrm{mg})$.

\subsection{Spectral Data}

Lunagrad A (1). Slightly yellow, amorphous powder. $[\alpha]_{\mathrm{D}}^{25}+11.4($ c $0.1, \mathrm{MeOH})$. IR $(\mathrm{KBr}) v_{\max }$ $3420,1617,1509,1463,1270,1222,1169,1125,1076 \mathrm{~cm}^{-1}$. HR-MS (ESI) $\mathrm{m} / z$ calculated for $\mathrm{C}_{38} \mathrm{H}_{45} \mathrm{~N}_{2} \mathrm{O}_{7}$ 
$[\mathrm{M}+\mathrm{H}]^{+}$641.3227, found 641.3230. ${ }^{1} \mathrm{H}-\mathrm{NMR}\left(500 \mathrm{MHz}, \mathrm{CD}_{3} \mathrm{OD}\right)$ and ${ }^{13} \mathrm{C}-\mathrm{NMR}\left(125 \mathrm{MHz}, \mathrm{CD}_{3} \mathrm{OD}\right)$ data (see Table 1).

Table 1. ${ }^{1} \mathrm{H}-\mathrm{NMR}(500 \mathrm{MHz})$ and ${ }^{13} \mathrm{C}-\mathrm{NMR}(125 \mathrm{MHz})$ data of compound $\mathbf{1}$ in $\mathrm{CD}_{3} \mathrm{OD}(\delta, \mathrm{ppm} ; J, \mathrm{~Hz})$ (Supplementary Information Figures S2 and S3).

\begin{tabular}{|c|c|c|c|c|c|c|c|}
\hline No. & & ${ }^{1} \mathrm{H}-\mathrm{NMR}$ & ${ }^{13} \mathrm{C}-\mathrm{NMR}$ & No. & & ${ }^{1} \mathrm{H}-\mathrm{NMR}$ & ${ }^{13} \mathrm{C}-\mathrm{NMR}$ \\
\hline 1 & $\mathrm{CH}$ & $3.82, \mathrm{~d}, 10.0$ & 63.0 & $1^{\prime}$ & $\mathrm{CH}$ & $4.00, \mathrm{dd}, 11.0,6.0$ & 64.5 \\
\hline 2 & $\mathrm{CH}_{3}$ & $2.27, \mathrm{~s}$ & 43.1 & $2^{\prime}$ & $\mathrm{CH}_{3}$ & $2.62, \mathrm{~s}$ & 42.5 \\
\hline 3 & $\mathrm{CH}_{2}$ & $\begin{array}{l}3.49 \text {, overlap } \\
2.91 \text {, overlap }\end{array}$ & 45.3 & $3^{\prime}$ & $\mathrm{CH}_{2}$ & $\begin{array}{c}3.47, \mathrm{~m} \\
2.78, \text { overlap }\end{array}$ & 45.7 \\
\hline 4 & $\mathrm{CH}_{2}$ & $\begin{array}{c}\text { 2.92, overlap } \\
\text { 2.53, dd, } 14.5,4.5\end{array}$ & 23.7 & $4^{\prime}$ & $\mathrm{CH}_{2}$ & $\begin{array}{c}3.01, \mathrm{~m} \\
2.86 \text {, overlap }\end{array}$ & 26.0 \\
\hline 5 & C & - & 124.0 & $5^{\prime}$ & $\mathrm{C}$ & - & 129.1 \\
\hline 6 & $\mathrm{CH}$ & $6.42, \mathrm{~s}$ & 107.3 & $6^{\prime}$ & $\mathrm{CH}$ & $6.66, \mathrm{~s}$ & 113.7 \\
\hline 7 & $\mathrm{C}$ & - & 153.0 & $7^{\prime}$ & $\mathrm{C}$ & - & 150.3 \\
\hline 7-OMe & $\mathrm{CH}_{3}$ & $3.73, \mathrm{~s}$ & 56.4 & $7^{\prime}-\mathrm{OMe}$ & $\mathrm{CH}_{3}$ & $3.37, \mathrm{~s}$ & 56.1 \\
\hline 8 & $\mathrm{C}$ & - & 139.3 & $8^{\prime}$ & $\mathrm{C}$ & - & 145.2 \\
\hline 8-OMe & $\mathrm{CH}_{3}$ & $3.15, \mathrm{~s}$ & 60.7 & & & - & \\
\hline 9 & $\mathrm{C}$ & - & 149.4 & $9^{\prime}$ & $\mathrm{CH}$ & $6.01, \mathrm{~s}$ & 121.4 \\
\hline 10 & C & - & 129.3 & $10^{\prime}$ & $\mathrm{C}$ & - & 129.0 \\
\hline 11 & $\mathrm{CH}_{2}$ & $\begin{array}{l}2.76, \mathrm{dd}, 14.5,10.0 \\
2.46, \mathrm{~d}, 14.5\end{array}$ & 42.6 & $11^{\prime}$ & $\mathrm{CH}_{2}$ & $\begin{array}{c}3.27, \mathrm{dd}, 12.5,6.0 \\
2.87, \text { overlap }\end{array}$ & 37.5 \\
\hline 12 & $\mathrm{C}$ & - & 135.8 & $12^{\prime}$ & $\mathrm{C}$ & - & 136.7 \\
\hline 13 & $\mathrm{CH}$ & $6.56, d, 1.6$ & 116.7 & $13^{\prime}$ & $\mathrm{CH}$ & $7.43, d, 8.2$ & 131.8 \\
\hline 14 & $\mathrm{C}$ & - & 151.0 & $14^{\prime}$ & $\mathrm{CH}$ & $7.05, d, 8.2$ & 122.9 \\
\hline 15 & $\mathrm{C}$ & - & 148.7 & $15^{\prime}$ & $\mathrm{C}$ & - & 155.1 \\
\hline 15-OMe & $\mathrm{CH}_{3}$ & $3.89, \mathrm{~s}$ & 56.8 & - & - & - & - \\
\hline 16 & $\mathrm{CH}$ & $6.92, d, 8.2$ & 113.2 & $16^{\prime}$ & $\mathrm{CH}$ & $6.76, d, 8.2$ & 122.8 \\
\hline 17 & $\mathrm{CH}$ & $6.86, d, 8.2$ & 124.4 & $17^{\prime}$ & $\mathrm{CH}$ & $6.38, d, 8.2$ & 133.9 \\
\hline
\end{tabular}

Lunagrad B (2). White, amorphous powder. $[\alpha]_{\mathrm{D}}^{25}-37.8\left(c\right.$ 0.1, MeOH). IR (KBr) $v_{\max } 3230$, 1610, 1450, 1221, 1188, $1095 \mathrm{~cm}^{-1}$. HR-MS (ESI) $\mathrm{m} / z$ calculated for $\mathrm{C}_{25} \mathrm{H}_{33} \mathrm{O}_{13}[\mathrm{M}+\mathrm{H}]^{+}$541.1921, found 541.1917. ${ }^{1} \mathrm{H}-\mathrm{NMR}\left(500 \mathrm{MHz}, \mathrm{CD}_{3} \mathrm{OD}\right)$ and ${ }^{13} \mathrm{C}-\mathrm{NMR}\left(125 \mathrm{MHz}, \mathrm{CD}_{3} \mathrm{OD}\right)$ data (see Table 2).

Table 2. ${ }^{1} \mathrm{H}-\mathrm{NMR}(500 \mathrm{MHz})$ and ${ }^{13} \mathrm{C}-\mathrm{NMR}(125 \mathrm{MHz})$ data of compound 2 in $\mathrm{CD}_{3} \mathrm{OD}(\delta, \mathrm{ppm} ; \mathrm{J}, \mathrm{Hz})$ (Supplementary Information Figures S11 and S12).

\begin{tabular}{|c|c|c|c|c|c|c|c|}
\hline No. & & ${ }^{1}$ H-NMR & ${ }^{13} \mathrm{C}-\mathrm{NMR}$ & No. & & ${ }^{1} \mathrm{H}-\mathrm{NMR}$ & ${ }^{13}$ C-NMR \\
\hline $1^{\prime}$ & $\mathrm{C}$ & - & 136.6 & $1^{\prime \prime}$ & $\mathrm{C}$ & - & 153.9 \\
\hline $2^{\prime}, 6^{\prime}$ & $\mathrm{CH}$ & $7.27, d, 8.4$ & 129.5 & $2^{\prime \prime}, 6^{\prime \prime}$ & $\mathrm{CH}$ & $6.69, d, 8.8$ & 116.6 \\
\hline $3^{\prime}, 5^{\prime}$ & $\mathrm{CH}$ & $7.07, d, 8.4$ & 117.7 & $3^{\prime \prime}, 5^{\prime \prime}$ & $\mathrm{CH}$ & $6.96, d, 8.8$ & 119.4 \\
\hline $4^{\prime}$ & C & - & 158.5 & $4^{\prime \prime}$ & C & - & 152.5 \\
\hline $4^{\prime}$-O-Glu-1 & $\mathrm{CH}$ & $4.89, \mathrm{~d}, 7.2$ & 102.4 & $4^{\prime \prime}$-O-Glu-1 & $\mathrm{CH}$ & $4.73, \mathrm{~d}, 7.2$ & 103.7 \\
\hline $4^{\prime}$-O-Glu-2 & $\mathrm{CH}$ & 3.42 , overlap & 75.1 & $4^{\prime \prime}$-O-Glu-2 & $\mathrm{CH}$ & 3.42 , overlap & 75.0 \\
\hline $4^{\prime}-\mathrm{O}-\mathrm{Glu}-3$ & $\mathrm{CH}$ & 3.41, overlap & 78.2 & $4^{\prime \prime}$-O-Glu-3 & $\mathrm{CH}$ & 3.41, overlap & 78.0 \\
\hline $4^{\prime}-\mathrm{O}-\mathrm{Glu}-4$ & $\mathrm{CH}$ & 3.34 , overlap & 71.5 & $4^{\prime \prime}-\mathrm{O}-\mathrm{Glu}-4$ & $\mathrm{CH}$ & 3.34 , overlap & 71.4 \\
\hline $4^{\prime}-\mathrm{O}-\mathrm{Glu}-5$ & $\mathrm{CH}$ & 3.36 , overlap & 78.1 & $4^{\prime \prime}$-O-Glu-5 & $\mathrm{CH}$ & 3.36 , overlap & 78.0 \\
\hline $4^{\prime}-\mathrm{O}-\mathrm{Glu}-6$ & $\mathrm{CH}_{2}$ & $\begin{array}{l}3.88, \text { br.d, } 12.0 \\
3.69 \text {, br.d, } 12.0\end{array}$ & 62.6 & $4^{\prime \prime}$-O-Glu-6 & $\mathrm{CH}_{2}$ & $\begin{array}{l}3.88, \text { br.d, } 12.0 \\
3.69, \text { br.d, } 12.0\end{array}$ & 62.5 \\
\hline 1 & $\mathrm{CH}_{2}$ & $4.54, \mathrm{~s}$ & 64.9 & - & - & - & - \\
\hline
\end{tabular}

\section{Conclusions}

The first chemical investigation of the flowers of Cymbidium Lunagrad Eternal Green resulted in the isolation of a new alkaloid, named Lunagrad A (1), and a new aromatic glucoside, named Lunagrad B (2), together with nine known compounds, 3-11. These specific compounds provided further 
confirmation of the typical profile of secondary metabolites that are found in the orchid family, and might be useful for further biological studies.

Supplementary Materials: Copies of ${ }^{1} \mathrm{H},{ }^{13} \mathrm{C}, \mathrm{DEPT}, \mathrm{COSY}, \mathrm{HSQC}, \mathrm{HMBC}$ and ROESY spectra of new compounds. This material is available free of charge online.

Acknowledgments: Financial support from the Guiding Project from Fujian Province (No. 2015N0020), Natural Science Foundation of Fujian Province of China (No. 2016J05024), Fujian Agriculture and Forestry University Foundation for Outstanding Youth (No. XJQ201623) is gratefully acknowledged.

Author Contributions: Ming-An Ouyang conceived and designed the experiments. Li-Yan Song, Fang Huang and Yan Wang performed the experiments. Li-Yan Song, $\mathrm{Zu}$-Jian $\mathrm{Wu}$ and Ming-An Ouyang analyzed the data. Li-Yan Song composed the manuscript.

Conflicts of Interest: The authors declare no conflicts of interest.

\section{References}

1. Shang, X.; Guo, X.; Liu, Y.; Pan, H.; Miao, X.; Zhang, J. Gymnadenia conopsea (L.) R. Br.: A systemic review of the ethnobotany, phytochemistry, and pharmacology of an important Asian folk medicine. Front. Pharmacol. 2017, 8, 24. [CrossRef] [PubMed]

2. Bhattacharyya, P.; Van Staden, J. Ansellia africana (Leopard orchid): A medicinal orchid, species with untapped reserves of important biomolecules-A mini review. S. Afr. J. Bot. 2016, 106, 181-185. [CrossRef]

3. Hossain, M.M. Therapeutic orchids: Traditional uses and recent advances-An overview. Fitoterapia 2011, 82, 102-140. [CrossRef] [PubMed]

4. Yoshikawa, K.; Ito, T.; Iseki, K.; Baba, C.; Imagawa, H.; Yagi, Y.; Morita, H.; Asakawa, Y.; Kawano, S.; Hashimoto, T. Phenanthrene derivatives from Cymbidium Great Flower Marie Laurencin and their biological activities. J. Nat. Prod. 2012, 75, 605-609. [CrossRef] [PubMed]

5. Yoshikawa, K.; Otsu, M.; Ito, T.; Asakawa, Y.; Kawano, S.; Hashimoto, T. Aromatic constituents of Cymbidium Great Flower Marie Laurencin and their antioxidative activity. J. Nat. Med. 2013, 67, 217-221. [CrossRef] [PubMed]

6. Yoshikawa, K.; Baba, C.; Iseki, K.; Ito, T.; Asakawa, Y.; Kawano, S.; Hashimoto, T. Phenanthrene and phenylpropanoid constituents from the roots of Cymbidium Great Flower 'Marylaurencin' and their antimicrobial activity. J. Nat. Med. 2014, 68, 743-747. [CrossRef] [PubMed]

7. Yoshikawa, K.; Okahuji, M.; Iseki, K.; Ito, T.; Asakawa, Y.; Kawano, S.; Hashimoto, T. Two novel aromatic glucosides, marylaurencinosides D and E, from the fresh flowers of Cymbidium Great Flower 'Marylaurencin'. J. Nat. Med. 2014, 68, 455-458. [CrossRef] [PubMed]

8. EI Bialy, S.A.A.; Braun, H.; Tietze, L.F. Enantioselective synthesis of a-alkyl-malates as the pharmacophoric group of several natural alkaloids and glycosides. Eur. J. Org. Chem. 2005, 14, 2965-2972. [CrossRef]

9. Sahakitpichan, P.; Mahidol, C.; Disadee, W.; Chimnoi, N.; Ruchirawat, S.; Kanchanapoom, T. Glucopyranosyloxybenzyl deriva-tives of $(R)$-2-benzylmalic acid and (R)-eucomic acid, and an aromatic glucoside from the pseudobulbs of Grammatophyllum speciosum. Tetrahedron 2013, 69, 1031-1037. [CrossRef]

10. Lee, Y.K.; Woo, M.H.; Kim, Y.; Lee, S.H.; Jeong, B.S.; Chang, H.W.; San, J.K. Two new benzofurans from Gastrodia elata and their DNA topoisomerases I and II inhibitory activities. Planta Med. 2007, 73, 1287-1291. [CrossRef] [PubMed]

11. Engelhardt, C.; Petereit, F.; Anke, J.; Hensel, A. A new arbutin derivative from the herb of Myrothamnus flabellifolia Welw. Pharmazie 2007, 62, 558-559. [CrossRef] [PubMed]

12. Wu, Q.; Fu, D.X.; Hou, A.J.; Lei, G.Q.; Liu, Z.J.; Chen, J.K.; Zhou, T.S. Antioxidative phenols and phenolic glycosides from Curculigo orchioides. Chem. Pharm. Bull. 2005, 53, 1065-1067. [CrossRef] [PubMed]

13. Martinez, J.; Silvan, A.M.; Abad, M.J.; Bermejo, P.; Villar, A. Isolation of two flavonoids from Tanacetum microphyllum as PMA-induced ear edema inhibitors. J. Nat. Prod. 1997, 60, 142-144. [CrossRef] [PubMed]

14. Haribal, M.; Renwick, A.A. Oviposition stimulants for the monarch butterfly: Flavonol glycosides from Asclepias curassavica. Phytochemistry 1996, 41, 139-144. [CrossRef]

15. Mcnally, D.J.; Wurms, K.V.; Labbe, C.; Quideau, S.; Belanger, R.R. Complex C-glycosyl flavonoid phytoalexins from Cucumis sativus. J. Nat. Prod. 2003, 66, 1280-1283. [CrossRef] [PubMed] 
16. Guha, K.P.; Mukherjee, B.; Mukherjee, R. Bisbenzylisoquinoline Alkaloids-A Review. J. Nat. Prod. 1979, 42, 1-84. [CrossRef] [PubMed]

17. Schiff, P.L., Jr. Bisbenzylisoquinoline alkaloids. J. Nat. Prod. 1991, 54, 645-749. [CrossRef] [PubMed]

18. Angerhofer, C.K.; Guinaudeau, H.; Wongpanich, V.; Pezzuto, J.M.; Cordell, G.A. Antiplasmodial and cytotoxic activity of natural bisbenzylisoquinoline alkaloids. J. Nat. Prod. 1999, 62, 59-66. [CrossRef] [PubMed]

19. Wang, Y.; Zhong, D.; Chen, X.; Zheng, J. Identification of Quinone Methide Metabolites of dauricine in human liver microsomers and in rat bile. Chem. Res. Toxicol. 2009, 22, 824-834. [CrossRef] [PubMed]

20. Cheng, F. Dauricine. In Handbook of Metabolic Pathways of Xenobiotics; John Wiley and Sons: New York, NJ, USA, 2014; Volume 3, pp. 1181-1185.

21. Garcia, G.R.M.; Hennig, L.; Shelukhina, I.V.; Kudryavtsev, D.S.; Bussmann, R.W.; Tsetlin, V.I.; Giannis, A. Curare alkaloids: Constituents of a matisdart poison. J. Nat. Prod. 2015, 78, 2537-2544. [CrossRef] [PubMed]

Sample Availability: Samples of all compounds in the manuscripts are available from the authors. 